\title{
Pretreatment Geriatric Assessments of Elderly Patients with Glioma: Development and Implications
}

\author{
Yaning Wang\#, Binghao Zhao", Wanqi Chen, Lei Liu, Wenlin Chen, Lizhou Zhou, Ziren Kong, \\ Congxin Dai, Yu Wang*, Wenbin Ma*
}

Departments of Neurosurgery, Peking Union Medical College Hospital, Chinese Academy of Medical Sciences and Peking Union Medical College, Beijing, China

[Received February 2, 2019; Revised May 26, 2019; Accepted May 27, 2019]

\begin{abstract}
Glioma is the most frequent primary brain tumor affecting adults, and the most lethal type is glioblastoma (GBM); currently, the available therapies only provide palliation. The treatments for low-grade glioma (LGG) include neurosurgical resection, watchful waiting, radiotherapy and chemotherapy, while the therapeutic strategies for high-grade glioma (HGG), particularly in elderly patients, have evolved to include radiotherapy, chemotherapy, and targeted monotherapy based on the characteristics of the investigated patients. Proper assessments aiming to predict and achieve the most satisfying prognosis among patients prior to surgery, radiotherapy, chemotherapy, targeted therapy or immunotherapy help summarize the pretreatment characteristics of patients, providing doctors comprehensive information to consider while determining whether the patients could benefit from ongoing treatments and deciding the proper treatment strategy for subsequent phases. This article aims to rigorously review the most recent evidence and discuss current mainstream assessments before the initiation of proper treatments for glioma, thus highlighting the potential necessity of pretreatment assessments.
\end{abstract}

Key words: glioma, geriatric, assessment, pretreatment

Glioma is the most common intracranial primary malignant tumor in adults, and the most malignant type is glioblastoma (GBM), which has an increasing incidence among the elderly. The incidence in individuals older than 65 years (the threshold age for inclusion in the elderly population according to the NCCN guidelines) is 2.63 times higher than that in younger individuals [1,2]. Since an advanced age is associated with a poor prognosis and more complicated physical conditions leading to reduced tolerance and decreased efficacy of treatment, optimal treatment strategies must be developed, and broad assessments of patients' relevant health status must be performed before surgery, chemotherapy, radiotherapy (RT), targeted therapy or even immunotherapy. Proper assessments enable clinicians to provide precise and individual treatments in clinical practice. Notably, glioma has a relatively low incidence among all types of cancers; thus, sufficient high-quality studies or evidence may not be available for some subjects listed in this review. We do not simply constrain the information to glioma and address the significance of pretreatment assessments from the perspective of the common features shared by glioma and other similar cancers. Our study aims to review the most recent high-quality evidence from studies involving geriatric patients with glioma who must decide which type of treatment to undergo to receive the greatest possible benefit, namely, the most beneficial individual therapy and proper assessment strategy.

*Correspondence should be addressed to: Drs. Wenbin Ma and Yu Wang, Peking Union Medical College Hospital, Chinese Academy of Medical Sciences and Peking Union Medical College, Beijing, China. Email: mawb2001@ hotmail.com and ywang@pumch.cn. ${ }^{\# T h e}$ authors equally contributed this work.

Copyright: () 2019 Wang Y et al. This is an open-access article distributed under the terms of the Creative Commons Attribution License, which permits unrestricted use, distribution, and reproduction in any medium, provided the original author and source are credited. 
Table 1. Characteristics of Clinical Trials Relating to Treatments (Surgery, Radiotherapy, Chemotherapy and chemoradiotherapy) for Glioma.

\begin{tabular}{|c|c|c|c|c|c|c|}
\hline $\begin{array}{l}\text { First } \\
\text { author/published } \\
\text { year }\end{array}$ & $\begin{array}{l}\text { Patients' } \\
\text { characteristics } \\
\text { (mean age, M/F) }\end{array}$ & $\begin{array}{l}\text { Intervention } \\
\text { (number) }\end{array}$ & $\begin{array}{l}\text { Comparison } \\
\text { (number) }\end{array}$ & Results & $\begin{array}{l}\text { Follow- } \\
\text { up }\end{array}$ & Study design \\
\hline \multicolumn{7}{|l|}{ Surgery } \\
\hline Gupta et al/2018 [3] & $\begin{array}{l}6.3(3.3-17.5) \\
23 / 27\end{array}$ & biopsy & NA & $\begin{array}{l}\text { In } 50 \text { patients with DIPG going } \\
\text { biopsy, } 46 \text { successfully captured } \\
\text { tissue samples }\end{array}$ & $\begin{array}{l}\text { Followed } \\
\text { until } \\
\text { death }\end{array}$ & $\begin{array}{l}\text { Single-arm } \\
\text { clinical trial }\end{array}$ \\
\hline $\begin{array}{l}\text { Kellermann et al/ } \\
2017 \text { [4] }\end{array}$ & $\begin{array}{l}74(70-87) \\
129 / 101\end{array}$ & $\begin{array}{l}\text { stereotactic } \\
\text { biopsy }\end{array}$ & NA & $\begin{array}{l}\text { Two hundred and thirty nine of } 230 \\
\text { elderly glioma patients received } \\
\text { stereotactic biopsy, } 222 \text { achieved } \\
\text { histopathologic diagnosis, and } 171 \\
\text { received further adjuvant therapy }\end{array}$ & 1 year & $\begin{array}{l}\text { Retrospective } \\
\text { study }\end{array}$ \\
\hline $\begin{array}{l}\text { Tanaka et al/ } \\
2013[5]\end{array}$ & $\begin{array}{l}74.1(66-87) \\
61 / 44\end{array}$ & $\begin{array}{l}\text { stereotactic } \\
\text { biopsy (52) }\end{array}$ & surgery (53) & $\begin{array}{l}\text { Complications of postoperative } \\
\text { bleeding is higher in patients } \\
\text { undergoing stereotactic biopsy than } \\
\text { in lesion removal surgery }\end{array}$ & 5 year & $\begin{array}{l}\text { Retrospective } \\
\text { study }\end{array}$ \\
\hline $\begin{array}{l}\text { Ostrom et al/ } \\
2018[18]\end{array}$ & $\begin{array}{l}\text { NA (59-64), } \\
56 / 44\end{array}$ & NA & NA & $\begin{array}{l}\text { Incidence of glioma and 1-year and } \\
5 \text {-year survival rates vary } \\
\text { significantly by race and ethnicity } \\
\text { with non-Hispanic whites having } \\
\text { higher incidence and lower survival } \\
\text { rate. }\end{array}$ & 14 year & $\begin{array}{l}\text { Retrospective } \\
\text { study }\end{array}$ \\
\hline \multicolumn{7}{|l|}{ Radiotherapy } \\
\hline $\begin{array}{l}\text { Keime et al/ } \\
2007[40]\end{array}$ & 73 (70-85), 51/30 & $\begin{array}{l}\text { radiotherapy } \\
\text { plus supportive } \\
\text { care }(39)\end{array}$ & $\begin{array}{l}\text { supportive } \\
\text { care }(42)\end{array}$ & $\begin{array}{l}\text { Radiotherapy brings better outcome } \\
\text { than supportive care in geriatric } \\
\text { GBM patients }\end{array}$ & 4 year & RCT \\
\hline $\begin{array}{l}\text { Douw et al/ } \\
2009[41]\end{array}$ & $44.2,35 / 30$ & NA & NA & $\begin{array}{l}\text { Side effect of cognitive loss could } \\
\text { only be found in low-grade young } \\
\text { glioma patients with RT hindering } \\
\text { our decision making }\end{array}$ & 12 year & $\begin{array}{l}\text { Prospective } \\
\text { clinical study }\end{array}$ \\
\hline $\begin{array}{l}\text { Malmstrom et } \\
\mathrm{al} / 2012[42]\end{array}$ & $\begin{array}{l}\text { no less than } 60 \text {, } \\
118 / 80\end{array}$ & $\begin{array}{l}\text { hypofractionated } \\
\text { RT (98) }\end{array}$ & $\begin{array}{l}\text { standard RT } \\
(100)\end{array}$ & $\begin{array}{l}\text { OS in geriatric GBM patients } \\
\text { receiving hypofractionated RT is } \\
\text { comparable in those with standard } \\
\text { radiotherapy }\end{array}$ & 9 year & $\mathrm{RCT}$ \\
\hline Roa et al/ 2004 [43] & $\begin{array}{l}\text { elder than } 60 \text {, } \\
55 / 40\end{array}$ & $\begin{array}{l}\text { standard RT } \\
(48)\end{array}$ & $\begin{array}{l}\text { short-course } \\
\text { RT (47) }\end{array}$ & $\begin{array}{l}\text { OS in geriatric GBM patients } \\
\text { receiving hypofractionated RT is } \\
\text { comparable in those with common } \\
\text { radiotherapy }\end{array}$ & 5 year & RCT \\
\hline Roa et al/2015 [44] & $\begin{array}{l}\text { no less than } 50 \text {, } \\
46 / 52\end{array}$ & $\begin{array}{l}\text { short-course RT } \\
(50)\end{array}$ & $\begin{array}{l}\text { standard RT } \\
(48)\end{array}$ & $\begin{array}{l}\text { Hypofractionated radiotherapy } \\
\text { regimens did not reveal different OS }\end{array}$ & 3 year & RCT \\
\hline Bent et al/2005[45] & $38.8,191 / 115$ & $\begin{array}{l}\text { early RT (after } \\
\text { surgery) (154) }\end{array}$ & $\begin{array}{l}\text { deferred RT } \\
(152)\end{array}$ & $\begin{array}{l}\text { Early radiotherapy after surgery } \\
\text { lengthened PFS but not progression- } \\
\text { free survival (PFS) }\end{array}$ & 7.8 year & RCT \\
\hline \multicolumn{7}{|l|}{$\begin{array}{l}\text { Chemotherapy and } \\
\text { chemoradiotherapy }\end{array}$} \\
\hline $\begin{array}{l}\text { Malmstrom et } \\
\text { al/2012 [42] }\end{array}$ & $\begin{array}{l}\text { no less than } 60 \text {, } \\
173 / 118\end{array}$ & $\begin{array}{l}\text { TMZ and } \\
\text { hypofractionated } \\
\text { RT (191) }\end{array}$ & $\begin{array}{l}\text { standard RT } \\
(100)\end{array}$ & $\begin{array}{l}\text { Two weeks of massive fractionation } \\
\text { RT or single TMZ could benefit } \\
\text { geriatric GBM patients compared to } \\
\text { six-week RT regimen }\end{array}$ & 9 year & $\mathrm{RCT}$ \\
\hline Stupp et al/2009[56] & $360 / 213$ & $\begin{array}{l}\text { RT with } \\
\text { concomitant } \\
\text { adjuvant TMZ } \\
(287)\end{array}$ & RT (286) & $\begin{array}{l}\text { Six cycles of TMZ adjuvant } \\
\text { chemoradiotherapy prolongs the } \\
\text { survival of elderly patients with } \\
\text { GBM }\end{array}$ & 2 year & RCT \\
\hline $\begin{array}{l}\text { Perry JR et } \\
\text { al/2017[57] }\end{array}$ & $\begin{array}{l}73(65-90) \\
43 / 219\end{array}$ & $\begin{array}{l}\text { Short course RT } \\
\text { (40Gy/15F) with } \\
\text { concomitant } \\
\text { adjuvant TMZ } \\
(281)\end{array}$ & $\begin{array}{l}\text { Short course } \\
\text { RT }(281)\end{array}$ & $\begin{array}{l}\text { The addition of temozolomide to } \\
\text { short-course radiotherapy resulted in } \\
\text { longer survival than short-course } \\
\text { radiotherapy alone }\end{array}$ & $\begin{array}{l}\text { Almost } \\
\text { all } \\
\text { followed } \\
\text { until } \\
\text { death }\end{array}$ & RCT \\
\hline
\end{tabular}

Abbreviations: DIPG, diffuse intrinsic pontine glioma; OS, overall survival; PFS, progression-free survival; GBM, glioblastoma; RT, radiotherapy; TMZ, temozolomide; RCT, randomized controlled trial; NA, not available 


\section{Surgery Among Geriatric Patients with Glioma}

The appropriate surgical methods for geriatric patients with glioma remain controversial. Studies involving surgery are summarized in Table 1 [3-5,18]. According to the 2017 National Comprehensive Cancer Network (NCCN) Clinical Practice Guidelines in Oncology focusing on older adult oncology, patients with GBM aged greater than 70 years achieve better prognoses when their tumor lesions are completely removed than when they are partially removed. The results obtained in younger patients are similar to those obtained in elderly patients ( $\geq 70$ years) [6,7]. A key question is whether the different prognoses originate from the operative methods (total or partial removal) or differences in the participants enrolled in the trials. The use of multiple bits and single bits in an "open biopsy" through a craniotomy resection (surgical) or endoscopic procedure leads to histological or cytological diagnoses similar to those in a stereotactic biopsy. However, some indicators, such as intraoperative bleeding, the operation time, postoperative complications, postoperative bleeding, cognitive function loss, hospital stay, recovery time, etc., may be highly variable [8].

"Stereotactic biopsy", which is also known as stereotactically directed biopsy, was among the first minimally invasive procedures used in neurosurgical management. Due to advances in neuroimaging devices, numerous minimally invasive lesions are diagnosed at an increasing rate. Additionally, intraoperative magnetic resonance imaging (MRI) has transformed a blind procedure into a visual procedure. As geriatric patients ( $\geq 70$ years) may not successfully survive the arranged surgeries, approximately $20 \%$ of these patients may have unexpected complications; therefore, a stereotactic biopsy is a good choice. Currently, stereotactic biopsy provides a rapid histological or cytological diagnosis with a secure profile, thus establishing its wide use in the field of neurosurgery to obtain an accurate diagnosis and manage the treatment of the central nervous system.

Gupta et al. [3] reported data from 50 patients with diffuse intrinsic pontine glioma (DIPG) who underwent open biopsy. Among these patients, tissue samples were successfully removed from 46 patients, assisting the researchers in making conclusive diagnoses and further treatment decisions. After the initial diagnosis, a biopsy is regarded as a safe strategy in geriatric patients with glioma to guide subsequent treatment with a low operative risk. In another retrospective study [4], 229 of 230 elderly patients with glioma underwent stereotactic biopsy, including 222 patients who obtained a histopathologic diagnosis and 171 patients who received further adjuvant therapy. In summary, similar to a single biopsy, stereotactic biopsy is a reliable, safe surgical option and an optional preassessment method before relevant adjuvant therapy is performed. Stereotactic biopsy requires a smaller incision than open biopsy, which increases the uncertainty of patients' intracranial conditions; thus, surgeons are unable to determine the complete situation during stereotactic biopsy. Intraoperative bleeding in stereotactic biopsy appears to occur less frequently than that in open biopsy. In addition, regarding complications after surgery, such as postoperative bleeding, the risk of intracranial hemorrhage in patients undergoing stereotactic biopsy is significantly higher than that in patients undergoing standard lesion removal in an open biopsy [5]. Overall, the prognoses of elderly patients with glioma worsen with increasing age, and surgery for tumor lesions is still recommended as a relatively good strategy despite several acknowledged drawbacks and potential risks.

\section{Preoperative Assessments of Geriatric Patients with Glioma}

Preoperative assessments of elderly patients with glioma include assessments of cognitive function, complications, frailty, activities of daily living, quality of life, nutritional status, laboratory parameters and geriatric syndromes, and these assessments are of paramount importance when making treatment decisions and can assist in providing prognostic information [9]. To the best of our knowledge, age and the extent of resection (EOR) are two of the strongest prognostic factors in GBM; the prognosis and survival time of patients with glioma also vary by race and ethnicity [10-18]. The studies describing preoperative assessments are summarized in Table 2 [10-17].

Cognitive function is an essential component of all preoperative assessments and is deemed an independent prognostic factor among geriatric patients with glioma who are undergoing surgery and corresponding RT. Derek et al. and Johnson et al. [10] conducted a series of cognitive functional tests in 91 patients who were newly diagnosed with glioma and had undergone surgery without further treatment. The prognosis after surgery was worse among the elderly patients with glioma and was specifically related to poor communication and behavioral functions. Cognitive attention was also associated with unsatisfactory prognoses (all P-values <0.01). Notably, we could predict the postoperative prognoses of these patients based on the results of preoperative cognitive functional assessments.

The Mini-Mental State Examination (MMSE) [19] and Montreal Cognitive Assessment (MoCA) [20] are commonly used to assess patients' cognitive function in clinical practice. Recently, Rambeau et al.[11] performed a large-scale prospective cohort study to compare the effectiveness of the MMSE and MoCA in evaluating patients' cognitive function and revealed that the MoCA 
was superior in assessing patients' cognitive function because the MoCA identified more impairments in cognitive function than the MMSE.

Table 2. Preoperative, Preradiotherapy, Prechemotherapy Assessments for Glioma and Other Cancer Patients.

\begin{tabular}{|c|c|c|c|c|c|c|c|}
\hline $\begin{array}{l}\text { First } \\
\text { author/published } \\
\text { year }\end{array}$ & $\begin{array}{l}\text { Patients' } \\
\text { characteristics } \\
\text { (mean age, } \\
\text { M/F) }\end{array}$ & $\begin{array}{l}\text { Intervention } \\
\text { (number) }\end{array}$ & $\begin{array}{l}\text { Comparison } \\
\text { (number) }\end{array}$ & Results & $\begin{array}{l}\text { Follow- } \\
\text { up }\end{array}$ & $\begin{array}{l}\text { Study } \\
\text { design }\end{array}$ & $\begin{array}{l}\text { Assessment } \\
\text { items }\end{array}$ \\
\hline \multicolumn{8}{|l|}{$\begin{array}{l}\text { Preoperative } \\
\text { assessments }\end{array}$} \\
\hline $\begin{array}{l}\text { Johnson et } \\
\text { al/2012[10] }\end{array}$ & $53.9,55 / 36$ & $\begin{array}{l}\text { WAIS-R, } \\
\text { WAIS-III, } \\
\text { HVLT-R } \\
\text { questionnaire }\end{array}$ & NA & $\begin{array}{l}\text { Executive function and } \\
\text { attention are cognitive domains } \\
\text { related to prognosis of GBM }\end{array}$ & 9 year & $\begin{array}{l}\text { retrospective } \\
\text { study }\end{array}$ & $\begin{array}{l}\text { cognitive } \\
\text { function }\end{array}$ \\
\hline $\begin{array}{l}\text { Rambeau et } \\
\text { al/2018 [11] }\end{array}$ & $\begin{array}{l}78(70-93) \\
25 / 41\end{array}$ & MMSE (13) & MoCA (44) & $\begin{array}{l}\text { MoCA seems to be more } \\
\text { relevant to screen cognitive } \\
\text { impairment }\end{array}$ & 1 year & $\mathrm{RCT}$ & $\begin{array}{l}\text { cognitive } \\
\text { function }\end{array}$ \\
\hline $\begin{array}{l}\text { Fiorentino et } \\
\text { al/2012 [12] }\end{array}$ & $\begin{array}{l}72(65-81) \\
17 / 18\end{array}$ & RTCHT (35) & NA & $\begin{array}{l}\text { Comorbidity assessments is an } \\
\text { appropriate tool for predicting } \\
\text { prognosis of elderly patients } \\
\text { with GBM }\end{array}$ & 6 year & $\begin{array}{l}\text { single-arm } \\
\text { clinical trial }\end{array}$ & comorbidity \\
\hline $\begin{array}{l}\text { Ening et al/2015 } \\
\text { [13] }\end{array}$ & $\begin{array}{l}62(15-84) \\
117 / 116\end{array}$ & NA & NA & $\begin{array}{l}\text { Besides old age and low KPS } \\
\text { score, higher CCI is } \\
\text { significantly associated with } \\
\text { poor OS and PFS in dismal } \\
\text { GBM, hence decides patient } \\
\text { stratification }\end{array}$ & 5 year & $\begin{array}{l}\text { retrospective } \\
\text { review }\end{array}$ & comorbidity \\
\hline $\begin{array}{l}\text { Cloney et al/2015 } \\
\text { [14] }\end{array}$ & $\begin{array}{l}\text { no less than } 65 \text {, } \\
\text { NA }\end{array}$ & $\begin{array}{l}\text { surgical } \\
\text { resection }\end{array}$ & biopsy & $\begin{array}{l}\text { Frailer elderly GBM patients } \\
\text { are less likely to undergo } \\
\text { surgical resection, have longer } \\
\text { hospital stay, more } \\
\text { complications, and less OS }\end{array}$ & 12 year & $\begin{array}{l}\text { retrospective } \\
\text { study }\end{array}$ & frailty \\
\hline $\begin{array}{l}\text { Peters et al/2014 } \\
\text { [15] }\end{array}$ & $\begin{array}{l}\text { mean } 50 \\
161 / 76\end{array}$ & NA & NA & $\begin{array}{l}\text { Greater degree of fatigue was } \\
\text { associated with poor survival } \\
\text { in recurrent HGG patients, } \\
\text { which shows fatigue is an } \\
\text { independent predicator for OS } \\
\text { rather than QoL }\end{array}$ & 2 year & $\begin{array}{l}\text { prospective } \\
\text { cohort study }\end{array}$ & $\begin{array}{l}\text { fatigue and } \\
\text { QoL }\end{array}$ \\
\hline $\begin{array}{l}\text { Borg et al/2011 } \\
\text { [16] }\end{array}$ & $\begin{array}{l}\text { mean } 60.1 \text {, } \\
419 / 266\end{array}$ & NA & NA & $\begin{array}{l}\text { GBM patients with pre- } \\
\text { operative hypoalbuminaemia } \\
\text { status have less post-operative } \\
\text { OS than normal albumin }\end{array}$ & 10 year & $\begin{array}{l}\text { retrospective } \\
\text { study }\end{array}$ & $\begin{array}{l}\text { lab } \\
\text { indicators }\end{array}$ \\
\hline He et al/2017 [17] & $\begin{array}{l}44(5-78) \\
197 / 129\end{array}$ & $\begin{array}{l}\text { surgery } \\
\text { (some } \\
\text { received } \\
\text { aggressive } \\
\text { adjuvant } \\
\text { treatment) }\end{array}$ & NA & $\begin{array}{l}\text { Newly diagnosed HGG } \\
\text { patients with elevated } \\
\text { fibrinogen level and decreased } \\
\text { albumin levels have more risk } \\
\text { of tumor progression and death }\end{array}$ & 2 year & $\begin{array}{l}\text { single-arm } \\
\text { clinical trial }\end{array}$ & $\begin{array}{l}\text { lab } \\
\text { indicators }\end{array}$ \\
\hline \multicolumn{8}{|l|}{$\begin{array}{l}\text { Preradiotherapy } \\
\text { assessments }\end{array}$} \\
\hline $\begin{array}{l}\text { VanderWalde et } \\
\text { al/2017 [49] }\end{array}$ & $\begin{array}{l}72.5(65-92) \\
24 / 22\end{array}$ & NA & NA & $\begin{array}{l}\text { Cancer patients failed to } \\
\text { receive pre-treatment are more } \\
\text { likely to have low health- } \\
\text { related quality of life. }\end{array}$ & 2 year & $\begin{array}{l}\text { prospective } \\
\text { cohort study }\end{array}$ & $\begin{array}{l}\text { health- } \\
\text { related } \\
\text { quality of } \\
\text { life }\end{array}$ \\
\hline $\begin{array}{l}\text { Antonio et } \\
\text { al/2018 [50] }\end{array}$ & $\begin{array}{l}79.5(75-87) \\
76 / 9\end{array}$ & NA & NA & $\begin{array}{l}\text { Fit NSCLC patients have } \\
\text { longer mOS than medium-fit; } \\
\text { patients with higher VES-13 } \\
\text { will have shorter mOS and } \\
\text { high risk of G3-4 toxicity }\end{array}$ & 8 year & $\begin{array}{l}\text { prospective } \\
\text { cohort study }\end{array}$ & $\begin{array}{l}\text { geriatric } \\
\text { assessments }\end{array}$ \\
\hline
\end{tabular}




\begin{tabular}{|c|c|c|c|c|c|c|c|}
\hline $\begin{array}{l}\text { Pottel et al/2014 } \\
\text { [51] }\end{array}$ & $\begin{array}{l}72(65-86) \\
86 / 14\end{array}$ & NA & NA & $\begin{array}{l}\text { CGA helps to identify the } \\
\text { evolution of health problems } \\
\text { and is indicative of quality of } \\
\text { life in patients with head and } \\
\text { neck carcinoma }\end{array}$ & 2 year & $\begin{array}{l}\text { prospective } \\
\text { cohort study }\end{array}$ & $\begin{array}{l}\text { geriatric } \\
\text { assessments }\end{array}$ \\
\hline $\begin{array}{l}\text { Gielda et al/2011 } \\
\text { [52] }\end{array}$ & $\begin{array}{l}64(30-84) \\
22 / 32\end{array}$ & NA & NA & $\begin{array}{l}\text { Weight decrease strongly } \\
\text { correlates with declined } \\
\text { OS/PFS of NSCLC patients. } \\
\text { Weight change during } \\
\text { treatment should be treated as } \\
\text { potential predicator }\end{array}$ & 11 year & $\begin{array}{l}\text { prospective } \\
\text { cohort study }\end{array}$ & $\begin{array}{l}\text { nutritional } \\
\text { status }\end{array}$ \\
\hline $\begin{array}{l}\text { Fiorentino et } \\
\text { al/2012 [12] }\end{array}$ & $\begin{array}{l}\text { more than } 65 \text {, } \\
17 / 18\end{array}$ & NA & NA & $\begin{array}{l}\text { Elderly GBM patients with } \\
\text { lower CCI score will have a } \\
\text { longer OS than those with } \\
\text { higher }\end{array}$ & 6 year & $\begin{array}{l}\text { prospective } \\
\text { cohort study }\end{array}$ & comorbidity \\
\hline $\begin{array}{l}\text { Chaichana et } \\
\text { al/2011 [53] }\end{array}$ & $\begin{array}{l}\text { older than } 65 \text {, } \\
67 / 66\end{array}$ & NA & NA & $\begin{array}{l}\text { KPS score less than } 80 \text {, motor } \\
\text { deficit, language deficit, } \\
\text { cognitive deficit are } \\
\text { independently associated with } \\
\text { decreased OS of elderly GBM } \\
\text { patients }\end{array}$ & 10 year & $\begin{array}{l}\text { retrospective } \\
\text { study }\end{array}$ & $\begin{array}{l}\text { KPS score, } \\
\text { motor, } \\
\text { language } \\
\text { cognitive } \\
\text { function }\end{array}$ \\
\hline \multicolumn{8}{|l|}{$\begin{array}{l}\text { Prechemotherapy } \\
\text { assessments }\end{array}$} \\
\hline $\begin{array}{l}\text { Wick et } \\
\text { al/2017[47] }\end{array}$ & $\begin{array}{l}57.7(21.2- \\
82.3), 265 / 172\end{array}$ & $\begin{array}{l}\text { lomustine } \\
\text { plus } \\
\text { bevacizumab } \\
(288)\end{array}$ & $\begin{array}{l}\text { lomustine } \\
\text { alone (149) }\end{array}$ & $\begin{array}{l}\text { Despite somewhat prolonged } \\
\text { PFS, lomustine plus } \\
\text { bevacizumab did not confer a } \\
\text { survival advantage over } \\
\text { treatment with lomustine alone } \\
\text { in glioblastoma patients. The } \\
\text { combined therapy affected } \\
\text { neither health related quality of } \\
\text { life nor neurocognitive } \\
\text { function. The MGMT status is } \\
\text { prognostic }\end{array}$ & 3 year & $\mathrm{RCT}$ & $\begin{array}{l}\text { cognitive } \\
\text { functiion }\end{array}$ \\
\hline $\begin{array}{l}\text { Aparicio et } \\
\text { al/2013[59] }\end{array}$ & $\begin{array}{l}80(75-91) \\
66 / 57\end{array}$ & $\begin{array}{l}\text { fluorouracil } \\
(62)\end{array}$ & $\begin{array}{l}\text { fluorouracil } \\
\text { with } \\
\text { irinotecan } \\
(61)\end{array}$ & $\begin{array}{l}\text { Cognitive function and } \\
\text { autonomy impairment assessed } \\
\text { by MMSE, IADL, MMSE are } \\
\text { predictive of severe toxicity or } \\
\text { unexpected hospitalization of } \\
\text { elderly metastatic colorectal } \\
\text { cancer patients }\end{array}$ & 7 year & RCT & $\begin{array}{l}\text { cognitive } \\
\text { function, } \\
\text { autonomy } \\
\text { impairment }\end{array}$ \\
\hline $\begin{array}{l}\text { Aaldriks et } \\
\text { al/2011[60] }\end{array}$ & $\begin{array}{l}77(71-92), \\
90 / 112\end{array}$ & NA & NA & $\begin{array}{l}\text { Inferior MNA and MMSE } \\
\text { scores increase the probability } \\
\text { of elderly cancer patients not } \\
\text { to complete hemotherapy }\end{array}$ & 3 year & $\begin{array}{l}\text { prospective } \\
\text { cohort study }\end{array}$ & $\begin{array}{l}\text { MNA, } \\
\text { MMSE }\end{array}$ \\
\hline
\end{tabular}

Abbreviations: GBM, glioblastoma; WAIS-R, wechsler Adult Intelligence Scale-revised; WISC-III, Wechsler Intelligence Scale for Children-III; HVLT-R:Hopkins Verbal Learning Test-Revised; RCT, randomized controlled trial; MMSE, Mini-mental State Examination; MoCA, Montreal Cognitive Assessment; RTCHT, radiochemotherapy; CCI, Charlson comorbidities index; KPS, Karnofsky score; MGMT, O6-methylguanine-DNA methyltransferase; mOS, median overall survival; PFS, progression-free survival; HGG, high grade glioma; QoL, quality of life; NSCLC, non-small cell lung cancer; VES-13, The Vulnerable Elderly Survey 13; G3-4, grade 3-4; IADL, Instrumental Activities of Daily Living Scale; NMA, Mini Nutritional Assessment; NA, not available.

Proper comorbidity assessments can help clinicians evaluate the overall physical conditions of older patients because of their poor tolerance for surgeries compared to adults. Fiorentino et al. [21] used the Charlson Comorbidity Index (CCI) to evaluate the comorbidities of elderly patients with GBM. Thirty-three participants were enrolled in their study, and the patients with the lower CCI scores had significantly longer overall survival (OS). Similarly, in a retrospective study involving 233 patients who were newly diagnosed with GBM, Ening et al. [13] investigated the associations between patients' OS and baseline characteristics, clinical treatment conditions and comorbidities. Poor OS and progression-free survival (PFS) were significantly correlated with an older age ( $>65$ years), low Karnofsky performance scores (KPSs) $(\leq 70)$ or a high CCI (>3). Based on the abovementioned studies, the CCI is a useful tool to comprehensively and effectively evaluate the comorbidities of patients with glioma, particularly elderly patients with GBM.

Assessments of frailty in elderly patients are deemed an essential component of the Comprehensive Geriatric Assessment (CGA). Michael Cloney et al.[14] further investigated the status of frailty in elderly patients, particularly elderly patients with GBM. In their 
retrospective study, the researchers found that severely frail individuals were less likely to have their lesions completely removed $(\mathrm{P}=0.02)$, had a relatively longer hospital stay $(\mathrm{P}=0.0061)$, had a higher risk of developing surgical complications $(\mathrm{P}=0.0123)$ and had a shorter $\mathrm{OS}$ $(\mathrm{P}=0.0028)$. According to previously reported evidence, a considerable number of neurosurgeons optimize their clinical decision-making processes for intended surgical candidates based on the results of frailty status assessments and cognitive function tests. The abovementioned studies addressed the significant role of geriatric assessments in determining the frailty status of geriatric patients with glioma. The FRAIL SCALE [22] is recommended as a standard method for evaluating the frailty status.

Currently, the quality of life is becoming a popular indicator of the conditions associated with prognosis and used to predict patient prognosis. In a prospective study involving 237 patients with recurrent high-grade glioma (HGG), Katherine B. Peters et al. [15] aimed to investigate the effects of the quality of life and frailty status on the prognosis of these patients using corresponding questionnaires. According to a strict statistical analysis, the quality of life was not an independent predictor of the prognosis of patients with HGG. However, patients with glioma who recorded low quality of life (QLQ) scores were likely to suffer from communication difficulties, logic disorders and a loss of motor function, which are imperative factors in predicting prognosis. Clinical practitioners have always adopted the Quality of Life Questionnaire C30 (QLQ-C30) [23] to assess the quality of life in patients with cancer. The Quality of Life Questionnaire BN20 (QLQ-BN20) has been used in combination with the QLQ-C30 in patients with glioma. The Functional Assessment of Cancer Therapy-Brain (FACT-Br) questionnaire is widely used in patients with brain cancer and mainly aims to assess the QOL according to general, social/family, emotional and functional brain cancer-specific issues, including concentration, memory, seizures, eyesight, hearing, speech, personality, expression of thoughts, weakness, coordination, and headache [24]. Both the QLQ-BN20 and FACT-Br are regarded as valid and reliable tools in populations with primary brain cancer. When applying these two tools, we must balance the strengths and weaknesses of each item. Another tool, i.e., the Short Form Health Survey-36 (SF-36), is a 36-item, patientreported survey of patient health. The SF-36 contains eight 0-100-point scales with equal weights. The eight scales include vitality, physical functioning, bodily pain, general health perceptions, physical functioning, emotional functioning, social functioning, and mental health and are commonly used to assess the health status of individuals. Despite its wide use in health status evaluations, the SF-36 has limitations as the survey does not consider a sleep variable and has a low response rate in elderly patients $[25,26]$. The SF-36 should be used cautiously based on these limitations.

Hemoglobin concentrations and serum albumin levels have been used to conveniently and accurately assess the nutritional status of patients with glioma. The serum albumin level is an important indicator of the systemic inflammatory response and nutritional status of patients and indicates the prognosis of patients with bladder cancer, ovarian cancer, soft tissue sarcoma, breast cancer, etc. [27-30]. According to Borg and Schwartzbaum et al. [16, 31], low serum albumin levels are significantly correlated with a shorter OS.

Fibrinogen is a key regulator of inflammation and cancer progression that has important functions in tumor cell proliferation, migration and angiogenesis [32]. Higher serum fibrinogen levels predict a poor OS in patients with rectal cancer, non-small cell lung cancer (NSCLC), renal cell carcinoma, breast cancer, etc. [3335]. In 2015, Matsuda et al. [36] first constructed the fibrinogen albumin (FA) score, representing a new assessment system for predicting the prognosis of patients with esophageal carcinoma based on the preoperative fibrinogen and albumin levels. He et al. [17] further analyzed the FA scores of 326 patients who were newly diagnosed with HGG and found that patients with HGG with higher FA scores exhibited poorer OS and PFS. The risk of tumor progression was 4 times greater in the patients with high fibrinogen and low albumin levels, and the risk of mortality was 4.23 times greater in such patients. Multivariate confounder analyses have shown that FA is an independent predictor of OS and PFS.

Recently, increasing studies $[37,38]$ have focused on the relationship between inflammatory factors and prognoses in patients with malignant tumors, and inflammatory factors have been included in several scales used for cancer prognosis assessments. Inflammatory factors, such as C-reactive protein and serum albumin, are also reliable and sensitive indicators of the acute response of tumor cells to proper interventions [39]. Although studies investigating laboratory biomarkers in elderly patients with GBM are still limited, routine assessments of the levels of hemoglobin, albumin, fibrinogen, and other inflammatory factors are recommended before surgery. Age and EOR are strongly predictive of the GBM prognosis as younger patients with a smaller EOR exhibit more satisfying prognoses than older patients with a larger EOR. Age, sex, race and ethnicity influence the incidence and survival time of glioma. For example, the incidence risk in non-Hispanic whites is twice as high as that in blacks and 25\% higher than that in Hispanic whites; the prognosis also varies according to race and ethnicity. In addition to these well-known factors, repeated procedures 
and surgeries are confirmed to improve patients' OS. The GBM subtype was confirmed to affect this parameter in a univariate analysis but not a Cox model $[18,40]$.

\section{RT in Geriatric Patients with Glioma}

A precise standard for the treatment of GBM in elderly patients does not exist. The optimal RT regimen in these patients remains to be established. According to the 2018 NCCN guidelines for older adult oncology, the decision to offer RT to older patients should be individualized based on several principles, including an evaluation of the benefits and risks associated with RT, consideration of the patient's status, and an understanding of the nature of the disease. The studies analyzing RT are summarized in Table 1 [40-45].

According to the results of the ANOCEF trial, RT leads to better outcomes than supportive care in elderly patients with GBM without reducing the quality of life or cognition[40]. Since evidence of cognitive side effects is available only for nonelderly patients with low-grade tumors, the risk of the loss of cognitive function with RT should not be included in the decision-making process regarding the treatment of elderly patients [41].

Several studies have reported the noninferiority of shorter hypofractionated RT protocols. Malmström et al. [42] and Roa et al. [43] performed prospective studies to improve the treatment of elderly patients and curtail lengthy RT treatments and showed that no difference in OS existed between elderly patients with GBM who received hypofractionated $\mathrm{RT}$ and patients receiving the commonly used RT. Regarding the reduced treatment time, a short-course RT regimen may be recommended as an attractive treatment option to improve treatment tolerability, particularly in frail patients. Currently, hypofractionated RT regimens include 40 Gy/15 F, 34 Gy/10 F, and $25 \mathrm{~Gy} / 5 \mathrm{~F}$, which do not yield significant differences in OS [44].

The onset of RT was studied in a prospective, randomized trial conducted by Van Den Bent et al., who assessed early and delayed RT in patients with low-grade glioma, astrocytoma and oligodendroglioma. Early RT after surgery lengthened the PFS but did not impact the OS [45]. The RT options available to elderly patients with a good status, low-grade gliomas, isocitrate dehydrogenase (IDH) mutations, epidermal growth factor receptor (EGFR) amplification, 1p/19q deficiencies or O6methylguanine-DNA methyltransferase (MGMT) promoter methylation considerably vary if these patients are carefully monitored[46, 47]. In addition to the aforementioned molecular markers, the statuses of other targeted genes, distinct biological processes, and mutations may be distinguished, and thus, the best RT alternative has not been verified [47]. Medical practitioners must maximize the benefits of individualized RT based on the patients' characteristics.

\section{Pre-RT Assessments of Geriatric Patients with Glioma}

Pre-RT assessments are designed to explore the relationship between the indicators before RT and the prognosis of the treatment. Pre-RT assessments of patients with central nervous system tumors, particularly gliomas, are currently being investigated based on known research directions, including age, fatigue, comorbidities, cognitive abilities and a new screening approach, i.e., CGA.

RT is well tolerated, and thus, age alone should not be a limiting factor in elderly patients with cancer[48]. Therefore, screening elderly patients who might benefit from RT using scientific assessment tools may be necessary to deliver quality cancer care. The studies performing pre-RT assessments are summarized in Table 2 [12, 49-53].

The CGA is a multidimensional, interdisciplinary approach aiming to assess patients' general health status, including functional, cognitive, nutritional, social, medical and psychological parameters, and is considered the most efficient method for screening the functional status and reserve capabilities of elderly patients [54]. The feasibility of using the CGA as a predictor of the quality of life and outcomes in elderly patients with cancer receiving $\mathrm{RT}$ has been reported in a prospective study conducted by Vander Walde $e t$ al., who found that a lower instrumental activities of daily living (IADL) score was associated with a continued decline and lack of recovery of health-related quality of life (HRQoL) [49]. Another prospective study showing the prognostic role of CGA was conducted by Antonio et al., who included 85 patients aged $\geq 75$ years with locally advanced NSCLC [50]. Additionally, Pottel et al. showed that the CGA was able to identify the evolution of multidimensional health problems and indicated the quality of life in elderly patients with head and neck carcinoma who were undergoing curative RT [51].

Nutritional deficiency is a common but serious condition that is underdiagnosed in elderly patients with cancer. Jager-Wittenaar et al. reported that the prevalence of malnutrition in patients treated for oral or oropharyngeal cancer is $16 \%$ [55]. A poor nutritional status could increase symptoms of radiation toxicity, such as dermatitis, sore throat, fatigue and anorexia. The strong correlation between weight changes during conformal RT (CRT) and OS/PFS reported by Gielda et al. suggests that the nutritional status might be useful as a complementary source of predictive information [52]. According to the 2018 NCCN guidelines for older adult oncology, nutritional support is recommended for patients receiving 
RT. The malnutrition screening tools commonly used in clinical practice include the body mass index (BMI), Mini Nutritional Assessment (MNA) scale score, etc.

Regarding fatigue, Peters et al. reviewed the records of 237 patients with recurrent $\mathrm{HGG}$ and found that fatigue was a strong independent predictor of survival [15].

Comorbidities are also associated with the prognosis after RT. Thirty-five patients older than 65 years with a KPS score greater than 60 and histological proof of GBM were treated at the same center and evaluated retrospectively. All patients underwent complete or partial excisions or biopsy, followed by chemoradiotherapy and adjuvant temozolomide (TMZ) therapy. The patients with low CCI scores experienced longer survival times than the patients with higher CCI scores [12].

Chaichana et al. [53] performed a retrospective analysis of 129 patients older than 65 years who experienced nonbiopsy removal of intracranial GBM at the same institution after controlling for perioperative and postoperative factors associated with outcomes. By the final follow-up, all patients had died, with a median survival of 7.9 months. The preoperative factors that were independently associated with reduced survival included a $\mathrm{KPS}<80(\mathrm{P}=0.001)$, chronic obstructive pulmonary disease $(\mathrm{P}=0.01)$, dyskinesia $(\mathrm{P}=0.01)$, speech impairment $(\mathrm{P}=0.005)$, recognition dysfunction $(\mathrm{P}=0.02)$, and tumor size $>4 \mathrm{~cm}(\mathrm{P}=0.002)$.

All aforementioned studies have shown that a variety of factors might affect the tolerance of elderly patients with glioma to RT. Hence, clinicians should conduct a comprehensive evaluation of the corresponding factors to design a more suitable treatment plan for elderly patients before deciding to administer RT, allowing the patient to obtain more benefits. However, current research is still limited, and high-level evidence is lacking. Additional studies are needed.

\section{Chemotherapy and Chemoradiotherapy for Geriatric Patients with Glioma}

When considering chemotherapy and chemotherapy protocols, the 2017 NCCN guidelines for geriatric oncology patients suggest that treatment with TMZ alone is no less effective than RT alone in elderly patients with astrocytoma and GBM (>64 years). The studies analyzing chemotherapy are summarized in Table 1 [42, 56, 57]. Compared with RT, the use of TMZ alone can prolong event-free survival in patients with MGMT promoter methylation [58]. In patients with GBM aged greater than 70 years, two weeks of massive fractionation RT or a single treatment with TMZ improved patient survival more than a standard six-week RT regimen. Furthermore, the study confirmed that the methylation status of the MGMT promoter played a guiding role in the use of TMZ
[42]. Concurrent chemoradiotherapy and 6-course TMZ adjuvant chemotherapy have been shown to prolong survival in elderly patients with GBM aged 60-70 years[56]. A recent phase 3 trial involving 562 patients aged $\geq 65$ years tested a new chemoradiation strategy in which TMZ was added to a shorter course of RT (40 Gy/15 F). The addition of TMZ to short-course radiotherapy was associated with a significant survival benefit over short-course radiotherapy alone among elderly patients with newly diagnosed glioblastoma, which was particularly evident in patients with a methylated MGMT status [57].

\section{Prechemotherapy Assessments of Geriatric Patients with Glioma}

Chemotherapy and prechemotherapy assessments have been conducted in elderly patients with cancer in many studies, which are summarized in Table 2 [47, 59, 60]. The results of these studies confirmed that general abilities in daily life, complications, the nutritional status, cognitive abilities, the psychosomatic state and frailty are related to possible toxic reactions during or after chemotherapy and the patient's tolerance to chemotherapy [61].

Thomas Aparicio et al. [59] conducted a prospective study involving elderly patients with metastatic gastrointestinal tumors. This study involved 123 patients aged on average 80 years, and their complications, cognition and daily living abilities were evaluated before chemotherapy. The results of this study showed that cognitive impairment (MMSE $\leq 27$ / 30; odds ratio (OR), 3.84 ) and poor daily living ability (OR, 4.67) were associated with chemotherapy-related grade 3-4 side effects in elderly patients with cancer. Based on this finding, these types of abilities must be evaluated before administering chemotherapy.

Another prospective study was conducted by Arti Hurria et al. [62]. This study analyzed 500 elderly patients with cancer aged 65 years or older (including patients with gastrointestinal cancer, breast cancer, urogenital carcinoma, etc.) recruited from seven medical centers. The treatment plans, laboratory investigations and geriatric assessments, including evaluations of cognitive function, complications, the psychological status, the nutritional status, etc., were evaluated. In addition, the occurrence of chemotherapy-related toxic reactions was also analyzed. Notably, 53\% of the patients developed grade 3-5 chemotherapy-related side effects after treatment. Eleven risk factors, including complications (creatinine clearance rate $<34 \mathrm{ml} / \mathrm{min}$ ), were identified. No significant correlations were observed among all parameters, such as frailty (restricted walking for 1 block) or mental state. 
During the same period, A. Aaldriks et al. [60] performed a comprehensive CGA before and after chemotherapy in elderly patients with cancer. The authors analyzed the results of various assessment items and patient mortality after chemotherapy. The nutritional status and cognitive function scores after chemotherapy were significantly worse than those before chemotherapy $(\mathrm{P}=0.001$ and $\mathrm{P}=0.04$, respectively). The patients with a low nutritional index score (MNA score) and a high frailty index score (Groningen Frailty Index, GFI) exhibited significantly higher mortality after chemotherapy. Fiftyone patients were re-evaluated after chemotherapy, and chemotherapy significantly reduced the cognitive function score (MMSE score) but had a minimal effect on the frailty index (GFI).

Regarding psychosis, a prospective study involving 83 elderly patients with ovarian cancer whose average age was 76 years was conducted by G. Freyer [63]. The researchers evaluated comorbidities, cognitive functioning, the nutritional status, mental and emotional states (i.e., whether they were associated with anxiety or depression) and drug delivery protocols. Depression $(\mathrm{P}=0.006)$, a poor general condition $(\mathrm{P}=0.026)$ and limited ability to live independently $(\mathrm{P}=0.048)$ were independent risk factors for severe chemotherapy-induced toxicity. Depression $(\mathrm{P}=0.003)$ and drug use (more than 6 types of drugs per day, $\mathrm{P}=0.043$ ) were independent predictors of the OS.

Harvey Jay Cohen et al. [64] conducted a study investigating frailty in elderly patients with cancer aged 65 years or older. Five hundred patients were assessed for frailty before chemotherapy and divided into "robust/nonweak" (50\%), "prefrail" (39\%) and "frail" $(11 \%)$ groups. The degree of frailty was correlated with the patients' prognosis and chemotherapy-induced toxicity. These results highlight the importance of evaluating patients' frailty before administering chemotherapy.

Prechemotherapeutic assessments have been widely performed in elderly patients with cancer. Alba Fiorentino et al. [21] studied the effects of comorbidities on the tolerance of elderly patients with GBM to RT and TMZ chemotherapy. Thirty-five patients with GBM older than 65 years were investigated, and all patients were treated with surgery, concurrent chemoradiotherapy and adjuvant TMZ chemotherapy. The patients with low complication index scores (CCI, <3) experienced a longer OS (22 months versus 10 months), but statistical evidence showing that comorbidity was a predictor of PFS was not found.

Based on the significant differences in tolerance to treatments between elderly patients and adult patients, pretreatment assessments are particularly important. All studies mentioned above reported a relationship between prechemotherapeutic assessments and tolerance to chemotherapy in elderly patients with cancer, thus confirming the importance of such evaluations. Clinicians should fully use these noninvasive approaches to provide safer and more effective treatments to elderly patients.

\section{Immunotherapy Assessments in Geriatric Patients with Glioma}

Immunotherapy intends to stimulate patients' immune systems and promote an immune-mediated anti-tumor response. This interesting topic has recently provided new therapeutic strategies for glioma.

Antibody-dependent cellular cytotoxicity (ADCC), cancer immunization, oncolytic viruses, chimeric antigen receptor T-cell (CAR-T) therapy, cytokine treatment, dendritic cell therapy, and checkpoint blockade all contribute to immunotherapy. The effective profiles of immunotherapy have been validated in patients with some other cancers, such as lung and breast tumors. Antibodies against HER2/neu and tumor-specific gangliosides are currently investigated for ADCC in patients with glioma $[65,66]$, and IL-2 therapy produced limited benefits [67]. A phase III trial investigating DCVax-L, which is an autologous tumor lysate-pulsed DC vaccine, has shown significantly prolonged $\mathrm{mOS}$ in patients with GBM[68]. CAR-T-mediated therapies targeting GBM markers, such as EGFRvIII, IL-13Ra2, HER2, and EphA2, are also being tested in ongoing clinical trials (NCT01454596, NCT02664363, NCT02209376, NCT 02208362, NCT02442297, NCT01109095, and NCT02575261).

Convincing real-world data regarding glioma remain insufficient or inconclusive, particularly in elderly patients, and few studies have performed preimmunotherapy assessments. The existing studies mainly focus on imaging evaluations, such as perfusion-weighted imaging (PWI), diffusion MRI, etc. Currently, the definitions of PFS and the clinical benefits of immunotherapy in patients with glioma are not well established. These radiological markers are reliable tools used to help assessments of the potential benefits of immunotherapy and distinguish real tumor progression from pseudoprogression to avoid misdiagnoses [69].

\section{Geriatric Syndrome and Caregivers}

Geriatric syndrome refers to a syndrome characterized by the same clinical manifestations or problems caused by diseases or other causes, including falls, dementia, urinary incontinence, delirium, syncope, depression, pain, insomnia, drug abuse and geriatric Parkinson's syndrome. Each component of geriatric syndrome can be specifically evaluated. For example, geriatric delirium is a type of acute ambiguous consciousness manifested as a loss of 
attention, feeling, mental health, and memory as well as psychomotor and sleep problems [70]. The identification of the cause of geriatric delirium and the administration of proper treatments are necessary; actually, geriatric delirium can resolve in a few days or a few months. When pathological lesions are present in patients' brains or cerebral vessels, delirium may be a risk factor for unsatisfactory prognoses. Assessments of geriatric delirium mainly involve the following aspects: 1 . a physical examination of the central nervous system to determine whether substantial pathological lesions are present in the patient's brain; 2. an evaluation of disruptions in the patient's vision or hearing; 3 . assessments of infections, electrolyte disorders or other types of illnesses; 4 . assessments of endocrine function to determine the hormone levels; and 5. evaluations of psychological stress and other social factors [71].

Table 3. Summary of Geriatric Syndrome and Caregiver.

\begin{tabular}{|c|c|c|c|c|c|c|}
\hline $\begin{array}{l}\text { First author/published } \\
\text { year }\end{array}$ & $\begin{array}{l}\text { Patients' } \\
\text { characteristics } \\
\text { (mean age, M/F) }\end{array}$ & Measurement/method & Results & Follow-up & $\begin{array}{l}\text { Study } \\
\text { design }\end{array}$ & $\begin{array}{l}\text { Assessment } \\
\text { items }\end{array}$ \\
\hline Kane et al/2012 [71] & NA & $\begin{array}{l}\text { eight geriatric } \\
\text { syndromes (multiple } \\
\text { comorbidities, cognitive } \\
\text { impairment, frailty, } \\
\text { disability, malnutrition, } \\
\text { impaired homeostasis } \\
\text { and chronic } \\
\text { inflammation) and } \\
\text { survival }\end{array}$ & $\begin{array}{l}\text { Geriatric syndrome } \\
\text { helps to understand the } \\
\text { survival for younger } \\
\text { old persons but } \\
\text { provides little } \\
\text { information for the } \\
\text { very old }\end{array}$ & NA & $\begin{array}{l}\text { systemat } \\
\text { ic } \\
\text { review }\end{array}$ & $\begin{array}{l}\text { geriatric } \\
\text { assessments }\end{array}$ \\
\hline $\begin{array}{l}\text { Svendsboe et al/2016 } \\
\text { [73] }\end{array}$ & $74.9,72 / 114$ & $\begin{array}{l}\text { caregiver burden (RSS), } \\
\text { cognitive function } \\
\text { (MMSE, CDR-SOB), } \\
\text { Neuropsychiatric } \\
\text { symptoms (NPI, } \\
\text { MADRS, UPDRS), } \\
\text { other variables (CIRS, } \\
\text { RDRS-2) }\end{array}$ & $\begin{array}{l}\text { Caregivers to people } \\
\text { with AD and to people } \\
\text { with DLB experience } \\
\text { moderate or high } \\
\text { caregiver burden with } \\
\text { increased risk of } \\
\text { psychiatric disorder in } \\
\text { early stage of dementia }\end{array}$ & NA & $\begin{array}{l}\text { cross- } \\
\text { sectional } \\
\text { study }\end{array}$ & caregiver \\
\hline
\end{tabular}

Abbrevations: RSS, Relative Stress Scale; MMSE, Mini Mental State Examination; CDR-SOB, Clinical Dementia Rating scale sum of boxes; NPI, Neuropsychiatric In- inventory; MADRS, Montgomery and Asberg Depression Rating Scale; UPDRS, The Unified Parkinson's Disease Rating Scale; CIRS, Cumulative Illness Rating Scale; RDRS-2, the Rapid Disability Rating Scale-2; AD, Alzheimer's disease; DLB, dementia with Lewy bodies; NA, not available

Caregivers are also crucial contributors to the process of managing geriatric patients with cancer. Caregivers help send patients to proper medical institutions on time, cope with emergencies, offer daily healthcare, decide the best treatment strategies, address complications, fill the gaps between medical workers and the patient's family members, promote communication among the patient's family members, resolve conflicts between patients and doctors and show empathy to special patients [72,73].

Excellent caregivers act as representatives not only of the patients but also of the patients' family members in addressing family conflicts or conflicts in medical administration. Proper, effective care also impacts the choice of the best treatment by improving compliance and decreasing the risk of severe complications. When elderly patients with cancer are unable to independently perform essential daily activities, their healthcare, quality of life and even normal life all likely depend on their caregivers $[74,75]$. In summary, patient prognoses after relevant therapies depend on their caregivers' choices.
The selection of an ideal caregiver for geriatric patients may improve their living conditions and determine their prognoses. The studies investigating geriatric syndromes and caregivers are summarized in Table 3 [71, 73].

Overall, geriatric patients with GBM represent a very heterogeneous group with epidemiology and management that differ from those in other patient groups. Survival is further limited in elderly patients who are often unable to tolerate multimodal therapy. Because an increasing number of patients are diagnosed with GBM and the aging population is increasing, comprehensive assessments of geriatric patients with glioma must be performed before all types of therapies are administered. Combined with current evidence-based medicine, complete assessments of geriatric patients with glioma, including evaluations of cognitive function, comorbidity, frailty, quality of life, nutritional status, laboratory indicators, etc., can assist clinicians in creating suitable, reasonable, and precise treatment strategies. In addition, these assessments should be performed by neurosurgeons worldwide. Patients with brain cancer primarily present to neurosurgery clinics for 
the removal of brain tumors using surgical procedures. Neurosurgeons conduct detailed examinations and adequate preoperative preparations (if they decide to perform surgeries) to ensure that the surgery is a safe process. These doctors also conduct pretreatment assessments to predict the prognoses and benefits of their patients through the assigned treatments; therefore, these doctors know whether the ongoing treatment produces a sufficient benefit and are able to identify proper alternative therapeutic strategies if the ongoing treatment is not the best choice. Furthermore, specific assessments of the presence of geriatric syndrome and the availability of caregivers could aid physicians in determining the balance between the potential benefits and risks of each oncological strategy for geriatric patients with GBM.

\section{Acknowledgements}

The authors thank Professor Renzhi Wang, MD and Professor Xinjie Bao, MD (Peking Union Medical College Hospital, PUMCH) for their advice. The work is supported by the Chinese Academy of Medical Sciences Innovation Fund for Medical Sciences (2016-I2M-2-001), the 2016 PUMCH Science Fund for Junior Faculty (pumch-2016-2.19) and the Fundamental Research Funds for the Central Universities (3332018029).

\section{References}

[1] Ostrom QT, Gittleman H, Xu J, Kromer C, Wolinsky Y, Kruchko C, et al. (2016). CBTRUS Statistical Report: Primary Brain and Other Central Nervous System Tumors Diagnosed in the United States in 2009-2013. Neuro Oncol, 18:v1-v75.

[2] Wenger NS, Solomon DH, Roth CP, MacLean CH, Saliba D, Kamberg CJ, et al. (2003). The quality of medical care provided to vulnerable communitydwelling older patients. Ann Intern Med, 139:740-747.

[3] Gupta N, Goumnerova LC, Manley P, Chi SN, Neuberg D, Puligandla M, et al. (2018). Prospective feasibility and safety assessment of surgical biopsy for patients with newly diagnosed diffuse intrinsic pontine glioma. Neuro Oncol, 20:1547-1555.

[4] Kellermann SG, Hamisch CA, Ruess D, Blau T, Goldbrunner R, Treuer H, et al. (2017). Stereotactic biopsy in elderly patients: risk assessment and impact on treatment decision. J Neurooncol, 134:303-307.

[5] Tanaka S, Meyer FB, Buckner JC, Uhm JH, Yan ES, Parney IF (2013). Presentation, management, and outcome of newly diagnosed glioblastoma in elderly patients. J Neurosurg, 118:786-798.

[6] Martinez R, Janka M, Soldner F, Behr R (2007). Gross-total resection of malignant gliomas in elderly patients: implications in survival. Zentralbl Neurochir, 68:176-181

[7] Vuorinen V, Hinkka S, Farkkila M, Jaaskelainen J (2003). Debulking or biopsy of malignant glioma in elderly people - a randomised study. Acta Neurochir (Wien), 145:5-10.

[8] Patel KS, Carter BS, Chen CC (2018). Role of Biopsies in the Management of Intracranial Gliomas. Prog Neurol Surg, 30:232-243.

[9] Mohile SG, Dale W, Somerfield MR, Schonberg MA, Boyd CM, Burhenn PS, et al. (2018). Practical Assessment and Management of Vulnerabilities in Older Patients Receiving Chemotherapy: ASCO Guideline for Geriatric Oncology. J Clin Oncol, 36:2326-2347.

[10] Johnson DR, Sawyer AM, Meyers CA, O'Neill BP, Wefel JS (2012). Early measures of cognitive function predict survival in patients with newly diagnosed glioblastoma. Neuro Oncol, 14:808-816.

[11] Rambeau A, Beauplet B, Laviec H, Licaj I, Leconte A, Chatel C, et al. (2018). Prospective comparison of the Montreal Cognitive Assessment (MoCA) and the Mini Mental State Examination (MMSE) in geriatric oncology. J Geriatr Oncol.

[12] Fiorentino A, Caivano R, Chiumento C, Cozzolino M, Clemente S, Pedicini P, et al. (2012). Comorbidity assessment and adjuvant radiochemotherapy in elderly affected by glioblastoma. Med Oncol, 29:3467-3471.

[13] Ening G, Osterheld F, Capper D, Schmieder K, Brenke $\mathrm{C}$ (2015). Charlson comorbidity index: an additional prognostic parameter for preoperative glioblastoma patient stratification. J Cancer Res Clin Oncol, 141:1131-1137.

[14] Cloney M, D'Amico R, Lebovic J, Nazarian M, Zacharia BE, Sisti MB, et al. (2016). Frailty in Geriatric Glioblastoma Patients: A Predictor of Operative Morbidity and Outcome. World Neurosurg, 89:362-367.

[15] Peters KB, West MJ, Hornsby WE, Waner E, Coan AD, McSherry $\mathrm{F}$, et al. (2014). Impact of health-related quality of life and fatigue on survival of recurrent high-grade glioma patients. J Neurooncol, 120:499506.

[16] Borg N, Guilfoyle MR, Greenberg DC, Watts C, Thomson S (2011). Serum albumin and survival in glioblastoma multiforme. J Neurooncol, 105:77-81.

[17] He ZQ, Duan H, Ke C, Zhang XH, Guo CC, Al-Nahari $\mathrm{F}$, et al. (2017). Evaluation of cumulative prognostic score based on pretreatment plasma fibrinogen and serum albumin levels in patients with newly diagnosed high-grade gliomas. Oncotarget, 8:49605-49614.

[18] Ostrom QT, Cote DJ, Ascha M, Kruchko C, BarnholtzSloan JS (2018). Adult Glioma Incidence and Survival by Race or Ethnicity in the United States From 2000 to 2014. JAMA Oncol, 4:1254-1262.

[19] Hansson L, Lithell H, Skoog I, Baro F, Banki CM, Breteler M, et al. (2000). Study on COgnition and Prognosis in the Elderly (SCOPE): baseline characteristics. Blood Press, 9:146-151.

[20] Nasreddine ZS, Phillips NA, Bedirian V, Charbonneau S, Whitehead V, Collin I, et al. (2005). The Montreal Cognitive Assessment, MoCA: a brief screening tool for mild cognitive impairment. J Am Geriatr Soc, 53:695-699. 
[21] Fiorentino A, Caivano R, Chiumento C, Cozzolino M, Clemente S, Pedicini P, et al. (2012). Comorbidity assessment and adjuvant radiochemotherapy in elderly affected by glioblastoma. Medical Oncology, 29:34673471 .

[22] Basic D, Shanley C (2015). Frailty in an older inpatient population: using the clinical frailty scale to predict patient outcomes. J Aging Health, 27:670-685.

[23] Aaronson NK, Ahmedzai S, Bergman B, Bullinger M, Cull A, Duez NJ, et al. (1993). The European Organization for Research and Treatment of Cancer QLQ-C30: a quality-of-life instrument for use in international clinical trials in oncology. J Natl Cancer Inst, 85:365-376.

[24] Chow R, Lao N, Popovic M, Chow E, Cella D, Beaumont J, et al. (2014). Comparison of the EORTC QLQ-BN20 and the FACT-Br quality of life questionnaires for patients with primary brain cancers: a literature review. Support Care Cancer, 22:25932598.

[25] Ware JE, Jr., Kosinski M, Gandek B, Aaronson NK, Apolone G, Bech P, et al. (1998). The factor structure of the SF-36 Health Survey in 10 countries: results from the IQOLA Project. International Quality of Life Assessment. J Clin Epidemiol, 51:1159-1165.

[26] White MK, Maher SM, Rizio AA, Bjorner JB (2018). A meta-analytic review of measurement equivalence study findings of the SF-36(R) and SF-12(R) Health Surveys across electronic modes compared to paper administration. Qual Life Res, 27:1757-1767.

[27] Kaya T, Sipahi S, Karacaer C, Nalbant A, Varim C, Cinemre H, et al. (2014). Evaluation of nutritional status with different methods in geriatric hemodialysis patients: impact of gender. Int Urol Nephrol, 46:23852391.

[28] Lin MY, Liu WY, Tolan AM, Aboulian A, Petrie BA, Stabile BE (2011). Preoperative serum albumin but not prealbumin is an excellent predictor of postoperative complications and mortality in patients with gastrointestinal cancer. Am Surg, 77:1286-1289.

[29] Fujii T, Sutoh T, Morita H, Katoh T, Yajima R, Tsutsumi S, et al. (2012). Serum albumin is superior to prealbumin for predicting short-term recurrence in patients with operable colorectal cancer. Nutr Cancer, 64:1169-1173.

[30] Han S, Li Z, Master LM, Master ZW, Wu A (2014). Exogenous IGFBP-2 promotes proliferation, invasion, and chemoresistance to temozolomide in glioma cells via the integrin betal-ERK pathway. Br J Cancer, 111:1400-1409.

[31] Schwartzbaum JA, Lal P, Evanoff W, Mamrak S, Yates A, Barnett GH, et al. (1999). Presurgical serum albumin levels predict survival time from glioblastoma multiforme. J Neurooncol, 43:35-41.

[32] Perisanidis C, Psyrri A, Cohen EE, Engelmann J, Heinze G, Perisanidis B, et al. (2015). Prognostic role of pretreatment plasma fibrinogen in patients with solid tumors: A systematic review and meta-analysis. Cancer Treat Rev, 41:960-970.

[33] Zhao J, Zhao M, Jin B, Yu P, Hu X, Teng Y, et al.
(2012). Tumor response and survival in patients with advanced non-small-cell lung cancer: the predictive value of chemotherapy-induced changes in fibrinogen. BMC Cancer, 12:330.

[34] Pichler M, Hutterer GC, Stojakovic T, Mannweiler S, Pummer K, Zigeuner R (2013). High plasma fibrinogen level represents an independent negative prognostic factor regarding cancer-specific, metastasis-free, as well as overall survival in a European cohort of non-metastatic renal cell carcinoma patients. Br J Cancer, 109:1123-1129.

[35] Wen J, Yang Y, Ye F, Huang X, Li S, Wang Q, et al. (2015). The preoperative plasma fibrinogen level is an independent prognostic factor for overall survival of breast cancer patients who underwent surgical treatment. Breast, 24:745-750.

[36] Matsuda S, Takeuchi H, Kawakubo H, Fukuda K, Nakamura R, Takahashi T, et al. (2015). Cumulative prognostic scores based on plasma fibrinogen and serum albumin levels in esophageal cancer patients treated with transthoracic esophagectomy: comparison with the Glasgow prognostic score. Ann Surg Oncol, 22:302-310.

[37] Han LH, Jia YB, Song QX, Wang JB, Wang NN, Cheng YF (2015). Prognostic significance of preoperative lymphocyte-monocyte ratio in patients with resectable esophageal squamous cell carcinoma. Asian Pac J Cancer Prev, 16:2245-2250.

[38] Guthrie GJ, Charles KA, Roxburgh CS, Horgan PG, McMillan DC, Clarke SJ (2013). The systemic inflammation-based neutrophil-lymphocyte ratio: experience in patients with cancer. Crit Rev Oncol Hematol, 88:218-230.

[39] Zitvogel L, Tesniere A, Kroemer G (2006). Cancer despite immunosurveillance: immunoselection and immunosubversion. Nat Rev Immunol, 6:715-727.

[40] Keime-Guibert F, Chinot O, Taillandier L, CartalatCarel S, Frenay M, Kantor G, et al. (2007). Radiotherapy for glioblastoma in the elderly. N Engl J Med, 356:1527-1535.

[41] Douw L, Klein M, Fagel SS, van den Heuvel J, Taphoorn MJ, Aaronson NK, et al. (2009). Cognitive and radiological effects of radiotherapy in patients with low-grade glioma: long-term follow-up. Lancet Neurol, 8:810-818.

[42] Malmstrom A, Gronberg BH, Marosi C, Stupp R, Frappaz D, Schultz H, et al. (2012). Temozolomide versus standard 6-week radiotherapy versus hypofractionated radiotherapy in patients older than 60 years with glioblastoma: the Nordic randomised, phase 3 trial. Lancet Oncol, 13:916-926.

[43] Roa W, Brasher PM, Bauman G, Anthes M, Bruera E, Chan A, et al. (2004). Abbreviated course of radiation therapy in older patients with glioblastoma multiforme: a prospective randomized clinical trial. J Clin Oncol, 22:1583-1588.

[44] Roa W, Kepka L, Kumar N, Sinaika V, Matiello J, Lomidze D, et al. (2015). International Atomic Energy Agency Randomized Phase III Study of Radiation Therapy in Elderly and/or Frail Patients With Newly 
Diagnosed Glioblastoma Multiforme. J Clin Oncol, 33:4145-4150.

[45] van den Bent MJ, Afra D, de Witte O, Ben Hassel M, Schraub S, Hoang-Xuan K, et al. (2005). Long-term efficacy of early versus delayed radiotherapy for lowgrade astrocytoma and oligodendroglioma in adults: the EORTC 22845 randomised trial. Lancet, 366:985990.

[46] Millward CP, Brodbelt AR, Haylock B, Zakaria R, Baborie A, Crooks D, et al. (2016). The impact of MGMT methylation and IDH-1 mutation on long-term outcome for glioblastoma treated with chemoradiotherapy. Acta Neurochir (Wien), 158:1943-1953.

[47] Wick W, Gorlia T, Bendszus M, Taphoorn M, Sahm F, Harting I, et al. (2017). Lomustine and Bevacizumab in Progressive Glioblastoma. N Engl J Med, 377:19541963.

[48] Smith GL, Smith BD (2014). Radiation treatment in older patients: a framework for clinical decision making. J Clin Oncol, 32:2669-2678.

[49] VanderWalde NA, Deal AM, Comitz E, Stravers L, Muss H, Reeve BB, et al. (2017). Geriatric Assessment as a Predictor of Tolerance, Quality of Life, and Outcomes in Older Patients With Head and Neck Cancers and Lung Cancers Receiving Radiation Therapy. Int J Radiat Oncol Biol Phys, 98:850-857.

[50] Antonio M, Saldana J, Linares J, Ruffinelli JC, Palmero R, Navarro A, et al. (2018). Geriatric assessment may help decision-making in elderly patients with inoperable, locally advanced non-smallcell lung cancer. Br J Cancer, 118:639-647.

[51] Pottel L, Lycke M, Boterberg T, Pottel H, Goethals L, Duprez F, et al. (2014). Serial comprehensive geriatric assessment in elderly head and neck cancer patients undergoing curative radiotherapy identifies evolution of multidimensional health problems and is indicative of quality of life. Eur J Cancer Care (Engl), 23:401412.

[52] Gielda BT, Mehta P, Khan A, Marsh JC, Zusag TW, Warren WH, et al. (2011). Weight gain in advanced non-small-cell lung cancer patients during treatment with split-course concurrent chemoradiotherapy is associated with superior survival. Int $\mathrm{J}$ Radiat Oncol Biol Phys, 81:985-991.

[53] Chaichana KL, Chaichana KK, Olivi A, Weingart JD, Bennett R, Brem H, et al. (2011). Surgical outcomes for older patients with glioblastoma multiforme: preoperative factors associated with decreased survival. Clinical article. J Neurosurg, 114:587-594.

[54] Aapro M, Extermann M, Repetto L (2000). Evaluation of the elderly with cancer. Ann Oncol, 11 Suppl 3:223229.

[55] Jager-Wittenaar H, Dijkstra PU, Vissink A, van Oort RP, van der Laan BF, Roodenburg JL (2011). Malnutrition in patients treated for oral or oropharyngeal cancer--prevalence and relationship with oral symptoms: an explorative study. Support Care Cancer, 19:1675-1683.

[56] Stupp R, Hegi ME, Mason WP, van den Bent MJ,
Taphoorn MJ, Janzer RC, et al. (2009). Effects of radiotherapy with concomitant and adjuvant temozolomide versus radiotherapy alone on survival in glioblastoma in a randomised phase III study: 5year analysis of the EORTC-NCIC trial. Lancet Oncol, 10:459-466.

[57] Perry JR, Laperriere N, O'Callaghan CJ, Brandes AA, Menten J, Phillips C, et al. (2017). Short-Course Radiation plus Temozolomide in Elderly Patients with Glioblastoma. N Engl J Med, 376:1027-1037.

[58] Wick W, Platten M, Meisner C, Felsberg J, Tabatabai $\mathrm{G}$, Simon M, et al. (2012). Temozolomide chemotherapy alone versus radiotherapy alone for malignant astrocytoma in the elderly: the NOA-08 randomised, phase 3 trial. Lancet Oncol, 13:707-715. Aparicio T, Jouve J-L, Teillet L, Gargot D, Subtil F, Le Brun-Ly V, et al. (2013). Geriatric Factors Predict Chemotherapy Feasibility: Ancillary Results of FFCD 2001-02 Phase III Study in First-Line Chemotherapy for Metastatic Colorectal Cancer in Elderly Patients. Journal of Clinical Oncology, 31:1464-1470.

[60] Aaldriks AA, Maartense E, le Cessie S, Giltay EJ, Verlaan HACM, van der Geest LGM, et al. (2011). Predictive value of geriatric assessment for patients older than 70 years, treated with chemotherapy. Critical Reviews in Oncology/Hematology, 79:205212.

[61] Kim J, Hurria A (2013). Determining chemotherapy tolerance in older patients with cancer. J Natl Compr Canc Netw, 11:1494-1502.

[62] Hurria A, Togawa K, Mohile SG, Owusu C, Klepin HD, Gross CP, et al. (2011). Predicting Chemotherapy Toxicity in Older Adults With Cancer: A Prospective Multicenter Study. Journal of Clinical Oncology, 29:3457-3465.

[63] Freyer G, Geay JF, Touzet S, Provencal J, Weber B, Jacquin JP, et al. (2005). Comprehensive geriatric assessment predicts tolerance to chemotherapy and survival in elderly patients with advanced ovarian carcinoma: a GINECO study. Annals of Oncology, 16:1795-1800.

[64] Cohen HJ, Smith D, Sun CL, Tew W, Mohile SG, Owusu C, et al. (2016). Frailty as determined by a comprehensive geriatric assessment-derived deficitaccumulation index in older patients with cancer who receive chemotherapy. Cancer, 122:3865-3872.

[65] Fleurence J, Cochonneau D, Fougeray S, Oliver L, Geraldo F, Terme M, et al. (2016). Targeting and killing glioblastoma with monoclonal antibody to Oacetyl GD2 ganglioside. Oncotarget, 7:41172-41185.

[66] Mineo JF, Bordron A, Quintin-Roue I, Loisel S, Ster $\mathrm{KL}$, Buhe V, et al. (2004). Recombinant humanised anti-HER2/neu antibody (Herceptin) induces cellular death of glioblastomas. Br J Cancer, 91:1195-1199.

[67] Daneman R, Zhou L, Kebede AA, Barres BA (2010). Pericytes are required for blood-brain barrier integrity during embryogenesis. Nature, 468:562-566.

[68] Prins RM, Soto H, Konkankit V, Odesa SK, Eskin A, Yong WH, et al. (2011). Gene expression profile correlates with $\mathrm{T}$-cell infiltration and relative survival 
in glioblastoma patients vaccinated with dendritic cell immunotherapy. Clin Cancer Res, 17:1603-1615.

[69] Aquino D, Gioppo A, Finocchiaro G, Bruzzone MG, Cuccarini V (2017). MRI in Glioma Immunotherapy: Evidence, Pitfalls, and Perspectives. J Immunol Res, 2017:5813951.

[70] Inouye SK, Studenski S, Tinetti ME, Kuchel GA (2007). Geriatric syndromes: clinical, research, and policy implications of a core geriatric concept. J Am Geriatr Soc, 55:780-791.

[71] Kane RL, Shamliyan T, Talley K, Pacala J (2012). The association between geriatric syndromes and survival. J Am Geriatr Soc, 60:896-904.

[72] Vallet-Regi M, Manzano M, Rodriguez-Manas L, Checa Lopez M, Aapro M, Balducci L (2017). Management of Cancer in the Older Age Person: An
Approach to Complex Medical Decisions. Oncologist, 22:335-342.

[73] Svendsboe E, Terum T, Testad I, Aarsland D, Ulstein I, Corbett A, et al. (2016). Caregiver burden in family carers of people with dementia with Lewy bodies and Alzheimer's disease. Int J Geriatr Psychiatry, 31:10751083.

[74] Balducci L, Extermann M (2000). Management of cancer in the older person: a practical approach. Oncologist, 5:224-237.

Pace A, Dirven L, Koekkoek JAF, Golla H, Fleming J, Ruda R, et al. (2017). European Association for Neuro-Oncology (EANO) guidelines for palliative care in adults with glioma. Lancet Oncol, 18:e330e340. 